\title{
Character Education on the Hindu Religious Education in Elementary Schools
}

\author{
I Nyoman Kiriana ${ }^{*}$, I Dewa Ayu Made Manu Okta Priantini ${ }^{2}$ \\ ${ }^{1}$ Universitas Hindu Negeri I Gusti Bagus Sugriwa \\ ${ }^{2}$ Universitas Dwijendra
}

\section{ART ICLE INFO}

Article history:

Received April 22, 2021

Revised April 30, 2021

Accepted July 14, 2021

Available online August 25, 2021

\section{Kata Kunci:}

Pendidikan Karakter, Proses

Pembelajaran, Pendidikan Agama

Hindu

Keywords:

Character Education, Learning

Process, Hindu Religious Education

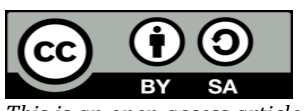

This is an open access article under the $\underline{C C}$ BY-SA license.

Copyright (C) 2021 by Author. Published by Universitas Pendidikan Ganesha.

\begin{abstract}
A B S T R A K
Permasalahan yang melatarbelakangi penelitian ini adalah masih kurangnya penanaman nilai-nilai karakter di kalangan peserta didik. Penelitian ini bertujuan untuk menganalisis pengimplementasian pendidikan karakter dalam proses pembelajaran pendidikan agama Hindu. Jenis penelitian ini adalah kualitatif dengan menggunakan pendekatan deskriptif kualitatif. Subjek dalam penelitian ini adalah guru dan siswa SD. Teknik pengumpulan data yang digunakan dalam penelitian ini yaitu observasi, wawancara, dan dokumentasi. Metode analisis data yang digunakan adalah analisis deskriptif kualitatif dengan tahapan: mencari dan menyusun secara sistematis data yang diperoleh dari hasil wawancara; mencatat temuan lapangan dan mendokumentasikannya dengan cara mengorganisasikan data ke dalam kategori; menjabarkan ke dalam unit-unit; melakukan sintesa; menyusun ke dalam pola; memilih yang penting dan yang akan dipelajari; dan membuat simpulan sehingga mudah dipahami oleh diri sendiri maupun orang lain. Hasil penelitian menunjukkan bahwa pengimplementasian pendidikan karakter hanya terdapat 14 nilai karakter yang ditemukan. Nilai karakter yang diteliti terdiri atas 18 nilai karakter dalam pengembangan pendidikan budaya dan karakter bangsa oleh Kemendikbud. Jadi, dapat ditarik simpulan bahwa penanaman nilai karakter sudah dilaksanakan dengan sangat baik walaupun belum maksimal.
\end{abstract}

\section{A B S T R A C T}

The problem behind this research was the lack of inculcation of character values among students. This research aims to analyze the implementation of character education in the learning process of Hindu religious education. This type of research was qualitative using a qualitative descriptive approach. The subjects in this research were elementary school teachers and students. Data collection techniques used in this research were observation, interviews and documentation. The data analysis method used was in the form of qualitative descriptive analysis, namely the process of systematically searching and compiling data obtained from interviews, field notes, and documentation, by organizing data into categories, breaking down into units, synthesizing, compiling into patterns, choosing which ones are important, and which will be studied, and making conclusions so that they are easily understood by themselves and others. Based on the result of this research and discussion described, it can be concluded that the implementation of character education was only able to find 14 characters. The character values achieved consist of 18 character values in the development of cultural and national character education by the Ministry of Education and Culture so that it can be concluded that the inculcation of values has been carried out well even though it was still maximal.

\section{INTRODUCTION}

Education is something that is very important for human life today (Fikriyah et al., 2020; Muliani \& Wibawa, 2019). Education can be obtained both formally and non-formally. Formal education is obtained through participation in programs that have been designed in a structured manner by an institution, department or ministry in a country, while non-formal education is knowledge gained by humans in everyday life (various experiences) either they feel alone or learned from others through observing or following (Fitron, 2020; Wijanarti et al., 2019). The development of education in Indonesia has undergone several improvements in order to provide quality education for students (Farindhni, 2018; Parwati, 2015). These developments brought the education system not only to think about mastery of the material or in terms of cognitive, but also to place character education as the soul of National Education (Maisaro et al., 2018; Omeri, 2015; Yusanti \& Kistian, 2020). This is done with the aim of developing the potential of students to become human beings who believe and fear God Almighty, have noble character, are healthy, knowledgeable, capable, creative, independent, and become democratic and responsible citizens (Islam, 2017; Omeri, 2015). 
Character itself is something that is not inherited, but something that is built continuously day by day through thoughts and actions, thoughts, actions for actions (Hamid et al., 2018; Julaeha, 2019). Character is also a person's ability to know the good, want the good, and do everything that is good (Ariyanti et al., 2019). While character education has the meaning of developing the ability of learners to behave well which is marked by the improvement of various abilities that will make humans as divine beings (subject to the concept of divinity), and carry out the mandate as leaders in the world (Wahyudi et al., 2019). Character education which is the main point in the current education system is one of the fundamental efforts in creating learning situations that meet the needs of students' self-development in learning interactions designed to form students with character (Islam, 2017; Samrin, 2016). It is hoped that through character education, students will be able to make students as individuals who are devoted to God Almighty, have strong faith so that they give birth to virtuous individuals, are tolerant of others, have fighting motivation and are able to work hard, achieve and be disciplined, have an attitude of respect for other people and democratic, responsible, creative and independent (Agung, 2017; Putri, 2018).

In fact, what is happening in the field today is that there are still many moral or character deviations from early childhood to university levels (Priantini \& Darwati, 2019). There are still many students who have the habit of cheating on tests or exams. The desire to graduate quickly and on time in an easy way without having to work hard so that students adopt various unethical ways (Swarniti, 2021b). Even students who do not pass, some of them are desperate to do actions that hurt themselves or even commit suicide (Santika, 2021). There are still many plagiarism of assignments among students. This deviation has explained that currently the character education that is being glorified has not been fully implemented properly (Purandina \& Winaya, 2020). On the other hand, in formal education, educators have a very important role in shaping the character of students by integrating character education during the implementation of learning (Santika, 2017). This statement is supported by the national character development policy for 2010-2025 which states that character education in teaching and learning activities in the classroom is carried out using an integrated approach in all subjects (Jumardi, 2017; Kistanti, 2019). From the policy statement, it means that the development of character education is not only integrated into Citizenship Education subjects, but also in Hindu religious education.

Hindu religious education aims to instill values in students to have Sradha and Bhakti to Brahman (God Almighty) and develop students' abilities, knowledge, attitudes and skills to become experts in Hindu religion and have knowledge, are capable, creative, independent and become a democratic citizen and be responsible for the understanding of the Vedas (Irawan, 2018; Widyana, 2018). Based on the results of observations on the implementation of religious education subjects at SD Negeri 2 Yehkuning, the integration of the implementation of character education has not been effective. This can be seen from the frequent finding of students who are truant and like to cheat on their friends' work, especially in this subject (Swarniti, 2021a). These problems certainly require more attention from teachers to take the initiative to emphasize character education. From the problems found, researchers are interested in identifying the implementation of character education in the implementation of learning religious education courses. Character education is basically very closely related to religious education (Priantini, 2021). Character education is defined as value education, character education (budi pekerti), moral education, character education (watak), which aims to develop the ability of students to make good and bad decisions and have the same goals as religious education (Rizqi et al., 2018). Character education aims to improve the quality of educational processes and outcomes that lead to the formation of the character and noble character of students in a complete, integrated, and balanced manner, in accordance with the competency standards of graduates in each educational unit (Yusanti \& Kistian, 2020). There are 18 points of character education values that can be applied to students, namely religious, honest, tolerance, discipline, hard work, creative, independent, democratic, curiosity, national spirit, love for the homeland, respect for achievement, friendly or communicative, love peace, likes to read, cares about the environment, cares about social and responsibility (Angga et al., 2020; Sutiyono, 2018).

In a character education institution, it is more directed to the formation of culture in the institution, namely the values that underlie behavior, customs, traditions, and symbols that are practiced by all the people around them (Surasmini et al., 2014). Given the great impact and benefits of character education, its implementation in various educational institutions needs to be really practiced, especially by educators. Educators without exception must participate in realizing character education in all scientific disciplines, especially religious education (Santika, 2018). Character education is inseparable from the cultivation of moral and religious values for students. Awareness of the importance of values, morals and religion as well as the development of teaching that combines faith and piety is in line with the essence of education as a means of change. In religious education, this character education aims not only to provide understanding and knowledge to students with knowledge and develop their skills, but also to develop their moral and religious aspects (Nuhamara, 2018). From this it can be seen that the roots of 
character education have actually existed in our education for a long time. The novelty of this study is that this study analyzes how the implementation of character education in elementary schools, especially in Hindu religious education subjects, is rarely studied. The purpose and focus of the research was the analysis of the implementation of character education in the learning process of Hindu religious education. The implication of this research was that by analyzing the application of character education, teachers or researchers can find out the level of character education possessed by students. So that further steps can be determined or ways to maximize the cultivation of character education in the students themselves.

\section{METHOD}

This research used a qualitative approach. In the qualitative approach, truth is relative, the implementation adapts to the situation and conditions encountered, the aim was to gain an understanding of reality through inductive thinking processes, qualitative research results are presented in descriptive narrative form. This type of research was descriptive (descriptive research) or a study aimed at describing existing phenomena that have taken place at this time or in the past. This research was conducted at the Hindu religious education study program at the State Hindu University of I Gusti Bagus Sugriwa. The subjects of this research were students of the Hindu religious education study program. The data collection techniques used were observation and interview techniques. Observation is a way of collecting data by conducting observations of ongoing activities while interviewing is an attempt to collect information by asking a number of questions orally, to be answered orally as well. The instrument used to collect data in this research consisted of an observation sheet and an interview sheet. The data analysis method used was in the form of qualitative descriptive analysis, namely the process of systematically searching and compiling data obtained from interviews, field notes, and documentation, by organizing data into categories, breaking down into units, synthesizing, compiling into patterns, choosing which ones are important, and which will be studied, and making conclusions so that they are easily understood by themselves and others (Sugiyono, 2014).

\section{RESULT AND DISCUSSION}

\section{Result}

Based on the results of observations and interviews that have been carried out, related to the implementation of character education, the results obtained during the implementation of learning have seen the implementation of character education although it has not been fully able to be raised. More detail is described as follows.

Table 1. Description of Research Results

\begin{tabular}{|c|c|}
\hline $\begin{array}{c}\text { Value of Character } \\
\text { Education }\end{array}$ & Research Results \\
\hline Religious & $\begin{array}{l}\text { The value of religious character can be seen when the teacher invites } \\
\text { his/her students to pray before the lecture starts and after the lecture } \\
\text { ends, and provides opportunities for his/her students to pray if there } \\
\text { are religious activities. }\end{array}$ \\
\hline Honest & $\begin{array}{l}\text { The value of honest character is found when the teacher prohibits } \\
\text { students from cheating on assignments to plagiarizing their friends' } \\
\text { assignments. Although not all students are able to instill this character } \\
\text { value, most of the students have been able to get used to being honest. } \\
\text { This is also evidenced by the results of the tasks collected that are not } \\
\text { exactly the same. }\end{array}$ \\
\hline Tolerance & $\begin{array}{l}\text { The value of the tolerance character is found when the teacher provides } \\
\text { the same service to all students regardless of social status, high } \\
\text { cognitive level and provides opportunities for students to work with } \\
\text { different groups according to their choice. In addition, during the } \\
\text { implementation of lectures, students in the class never discriminate } \\
\text { against their friends. }\end{array}$ \\
\hline Discipline & $\begin{array}{l}\text { Discipline character values are found when students arrive on time } \\
\text { according to the lecture hours that will start. In terms of the clothes } \\
\text { used there are no students who violate. In addition, students will not } \\
\text { leave the lecture before the teacher who teaches precedes to leave. }\end{array}$ \\
\hline
\end{tabular}




\begin{tabular}{|c|c|}
\hline $\begin{array}{c}\text { Value of Character } \\
\text { Education }\end{array}$ & Research Results \\
\hline Hard Work & $\begin{array}{l}\text { The value of the character of hard work is found when the teacher } \\
\text { requires students to explore their own knowledge and be able to create } \\
\text { a new work related to religious subjects or products that support } \\
\text { religious events. }\end{array}$ \\
\hline Creative & $\begin{array}{l}\text { The value of creative character is found when the teacher gives } \\
\text { assignments that give rise to creative ideas and provide opportunities } \\
\text { for students to work even more to create something new that can } \\
\text { support lectures. }\end{array}$ \\
\hline Independent & $\begin{array}{l}\text { The value of independent character is found when the teacher gives } \\
\text { assignments independently to students. It has been seen that the class } \\
\text { students are able to independently work on the assignments given so } \\
\text { that they can collect them on time. }\end{array}$ \\
\hline Love the Homeland & $\begin{array}{l}\text { The value of the character of love for the homeland was found that } \\
\text { when the teacher and students communicated they still used } \\
\text { Indonesian as the national language. }\end{array}$ \\
\hline Friendly/Communicative & $\begin{array}{l}\text { The value of friendly/communicative character is found when } \\
\text { conducting discussions in class. Students are given the opportunity to } \\
\text { ask questions or add answers, or just to share. Then the teacher } \\
\text { provides reinforcement or answers to straighten out what the students } \\
\text { do not understand. }\end{array}$ \\
\hline Love Peace & $\begin{array}{l}\text { The value of the peace-loving character is emphasized by the teacher } \\
\text { integrated with the delivery of lecture material. That every religion } \\
\text { teaches its people to always live in peace even with friends or the } \\
\text { surrounding community who embrace a different religion from it. }\end{array}$ \\
\hline Care & $\begin{array}{l}\text { The value of social caring character is found when the teacher always } \\
\text { creates harmony in the class and familiarizes his/her students with } \\
\text { mutual respect for each other. }\end{array}$ \\
\hline Responsibility & $\begin{array}{l}\text { The value of the character of responsibility is found when students are } \\
\text { able to complete the given task on time. In addition, students are } \\
\text { always responsible for the answers or assignments given so that no one } \\
\text { makes assignments carelessly. }\end{array}$ \\
\hline
\end{tabular}

\section{Discussion}

The implementation of learning that takes place in the classroom is a teaching and learning process that includes both the sense of hearing and the sense of sight. In the learning process, in addition to conveying material, teachers are also required to integrate character values in each implementation of learning, especially in religious education, therefore students are expected to have abilities not only in cognitive aspects, but also in psychomotor and affective aspects (Murniyetti et al., 2016; Pitriani, 2020). The implementation of learning by integrating character education is not only in the form of an explanation of instructional objectives but also in the form of giving an explanation of the character values contained in the competency standards and basic competencies. Religious education and awareness of religious values are the main motivators for the success of character education. However, religion cannot be used as a regulatory guide in living together in a society. In this modern, very multicultural era, it is still important to maintain religious values, but cannot be used as a solid basis for living together in society. Although religious education is important in helping to develop individual character, it is not an effective foundation for a stable social order in a pluralistic society. In this context, moral values will be more operational than religious values (Putra, 2018; Yusanti \& Kistian, 2020).

It is very important to develop character education especially in core ethical values such as caring, honesty, fairness, responsibility, and respect for self and others along with supporting performance values such as perseverance, high work ethic, and persistence-as the basis of character (Ramdhani, 2017; Surawati \& Suasthi, 2019). The institution itself must be committed to developing the character of students based on the values in question, defining them, in the form of behavior that can be observed in everyday school life, exemplifying these values, studying and discussing them, using them as a basis in human relations, and appreciate the manifestation of these values in schools and society. Optimizing the implementation of lectures by implementing character education can be achieved effectively, one of which is supported by the availability of learning resources in the form of guidebooks for implementing character-based learning. Apart from that, there are many things to do. Such as giving students problems 
that can stimulate or challenge themselves to further develop character education. Starting from giving tasks that require to work hard, respect and tolerate, be responsible, and be able to be disciplined about what has been done.

In a study which analyzed character education in tembang dolanan for elementary school students in Central Java, the results showed that it contained sixteen values of character education, namely religious, honest, tolerance, discipline, hard work, independent, democratic, curiosity, the spirit of nationalism, love for the homeland, appreciate achievements, friendly/communicative, love peace, care for the environment, care about social, and responsibility (Rahayu, 2021). So based on this, the application of character education can be well applied in the school, especially in the material for the dolanan song. Then the research who applied an inquiry approach to science subjects to develop students' character got the results that the use of an inquiry approach could develop students' characters, such as the character of cooperation, curiosity, and communicativeness (Putra, 2018). From the two research results, it can be concluded that character education can be applied to any subject.

\section{CONCLUSION}

Character education is basically very closely related to religious education. Character education is defined as value education, character education (budi pekerti), moral education, character education (watak), which aims to develop the ability of students to make good and bad decisions and have the same goals as religious education. In the learning process of Hindu religious education, it can be concluded that when referring to the 18 character values issued by the Ministry of Education and Culture, in total there are 12 character values that emerge from the 18 character values observed in learning activities. The application of character values during learning activities is very important, because it can shape the character and attitudes of students for capital in developing and continuing life both in the school environment and in the community environment as well as preparing mentally to face challenges in the future.

\section{REFERENCES}

Agung, I. (2017). Peran Fasilitator Guru dalam Penguatan Pendidikan Karakter (PPK). Perspektif Ilmu Pendidikan, 31(2), 106-119. https://doi.org/10.21009/pip.312.6.

Angga, P. M. W., Sudarma, I. K., \& Suartama, I. K. (2020). E-Komik Pendidikan untuk Membentuk Karakter dan Meningkatkan Hasil Belajar Siswa Kelas V pada Mata Pelajaran Bahasa Indonesia. Jurnal Edutech Undiksha, 8(2), 93. https://doi.org/10.23887/jeu.v8i2.28920.

Ariyanti, F., Rustopo, R., \& Putri, A. D. S. (2019). Analisis Nilai Karakter dalam Pembelajaran Tematik Tema Cita-Citaku. Indonesian Values and Character Education Journal, 2(1), 43-50. https://doi.org/10.23887/ivcej.v2i1.17942.

Farindhni, D. A. (2018). Pengembangan Media Video Animasi untuk Peningkatan Motivasi Belajar dan Karakter Demokratis Siswa Kelas V Sekolah Dasar. Jurnal Pendidikan Karakter, 8(2), 172-186. https://doi.org/10.21831/jpk.v8i2.21850.

Fikriyah, F., Rohaeti, T., \& Solihati, A. (2020). Peran Orang Tua dalam Meningkatkan Literasi Membaca Peserta Didik Sekolah Dasar. Dwija Cendekia: Jurnal Riset Pedagogik, 4(1), 94. https://doi.org/10.20961/jdc.v4i1.43937.

Fitron, M. (2020). Survei Tingkat Persepsi Siswa terhadap Konsep Pendidikan Jasmani di Sekolah Menengah Atas. Sport Science and Health, 2(5), 264-271. http://journal2.um.ac.id/index.php/jfik/article/view/11794.

Hamid, A., Jaenudin, R., \& Koryati, D. (2018). Analisis nilai-nilai karakter siswa pada pembelajaran ekonomi di SMA Negeri 2 Tanjung Raja. Jurnal PROFIT Kajian Pendidikan Ekonomi dan Ilmu Ekonomi, 5(1), 1-16. https://ejournal.unsri.ac.id/index.php/jp/article/view/5632/0.

Irawan, K. A. (2018). Analisis Implementasi Intergrasi Pendidikan Karakter dalam Pendidikan Agama Hindu di Pasraman Se-Jabodetabek. Jurnal PASUPATI, 5(2), 108-135. https: //doi.org/10.37428/pspt.v5i2.28.

Islam, S. (2017). Karakteristik Pendidikan Karakter; Menjawab Tantangan Multidimensional melalui Implementasi Kurikulum 2013. EDURELIGIA: Jurnal Pendidikan Agama Islam, 1(1), 89-100. https: //doi.org/10.33650/edureligia.v1i2.50.

Julaeha, S. (2019). Problematika Kurikulum dan Pembelajaran Pendidikan Karakter. Jurnal Penelitian Pendidikan Islam, 7(2), 157-182. https://doi.org/10.36667/jppi.v7i2.367.

Jumardi, J. (2017). Peranan Pelajaran Sejarah dalam Pengembangan Karakter Siswa melalui Pembelajaran Berbasis Nilai Sejarah Lokal di SMA Negeri 65 Jakarta Barat. Jurnal Pendidikan Sejarah, 6(2), 7080. https://doi.org/10.21009/JPS.062.08. 
Kistanti, D. (2019). Analisis Pelaksanaan Pendidikan Karakter dalam Pembelajaran Matematika di Kelas III SD Negeri 3 Teunom. Bina Gogik: Jurnal Ilmiah Pendidikan Guru Sekolah Dasar, 6(1). https: //www.ejournal.stkipbbm.ac.id/index.php/pgsd/article/view/410.

Maisaro, A., Wiyono, B. B., \& Arifin, I. (2018). Manajemen Program Penguatan Pendidikan Karakter Di Sekolah Dasar. JAMP: Jurnal Administrasi dan Manajemen Pendidikan, 1(3), 302-312. https: //doi.org/10.17977/um027v1i32018p302.

Muliani, N. K. D., \& Wibawa, I. M. C. (2019). Pengaruh Model Pembelajaran Inkuiri Terbimbing Berbantuan Video terhadap Hasil Belajar IPA. Jurnal Ilmiah Sekolah Dasar, 3(1), 107-114. https://doi.org/http://dx.doi.org/10.23887/jisd.v3i1.17664.

Murniyetti, M., Engkizar, E., \& Anwar, F. (2016). Pola Pelaksanaan Pendidikan Karakter terhadap Siswa Sekolah Dasar. Jurnal Pendidikan Karakter, https://journal.uny.ac.id/index.php/jpka/article/download/12045/8608 .

Nuhamara, D. (2018). Pengutamaan Dimensi Karakter dalam Pendidikan Agama Kristen. Jurnal Jaffray, 16(1), 93-114. https://doi.org/10.25278/jj71.v16i1.278.

Omeri, N. (2015). Pentingnya Pendidikan Karakter dalam Dunia Pendidikan. Manajer Pendidikan, 9(3). https: //ejournal.unib.ac.id/index.php/manajerpendidikan/article/viewFile/1145/953.

Parwati, N. N. (2015). Pengembangan Model Pembelajaran Pemecahan Masalah Berorientasi Kearifan Lokal pada Siswa SMP di Kota Singaraja. Jurnal Pendidikan Indonesia, 4(2), 612-622. https: //doi.org/10.23887/jpi-undiksha.v4i2.6058.

Pitriani, N. R. V. (2020). Transformasi Pendidikan di Era New Normal Perspektif Pendidikan Agama Hindu Ditinjau dari Segi Sosio-Etika pada Sekolah Tinggi Agama Hindu Negeri Mpu Kuturan Singaraja. Widyanatya, 2(2), 86-99. https://doi.org/10.32795/widyanatya.v2i02.1050.

Priantini, D. A. M. M. O. (2021). The Development of Teaching Video Media Based on Tri Kaya Parisudha in Educational Psychology Courses. Journal of Education Technology, 4(4), 448-455. https://doi.org/10.23887/jet.v4i4.29608.

Priantini, D. A. M. M. O., \& Darwati, G. M. (2019). Pengembangan Perangkat Pembelajaran Tematik Terpadu Berbasis Tri Hita Karana untuk Anak Sekolah Dasar. Seminar Nasional Inovasi dalam Penelitian Sains, Teknologi dan Humaniora-InoBali, 1111-1120. https://eproceeding.undwi.ac.id/index.php/inobali/article/view/93.

Purandina, I. P. Y., \& Winaya, I. M. A. (2020). Pendidikan Karakter di Lingkungan Keluarga Selama Pembelajaran Jarak Jauh pada Masa Pandemi COVID-19. Cetta: Jurnal Ilmu Pendidikan, 3(2), 270290. https://doi.org/10.37329/cetta.v3i2.454.

Putra, P. (2018). Penerapan Pendekatan Inkuiri pada Mata Pelajaran IPA untuk Mengembangkan Karakter Siswa di SDN 01 Kota Bangun. Muallimuna: Jurnal Madrasah Ibtidaiyah, 3(1), 28-47. https: //doi.org/10.31602/muallimuna.v3i1.953.

Putri, A. D. S. (2018). Keefektifan Modul Pembelajaran Menulis Karangan Berbasis Pendidikan Karakter pada Peserta Didik Kelas IV Sekolah Dasar. Jurnal Pendidikan Dasar, 6(2). https: //jurnal.fkip.uns.ac.id/index.php/diksar/article/view/12115/8630.

Rahayu, C. V. (2021). Analisis Pendidikan Karakter dalam Tembang Dolanan bagi Siswa Sekolah Dasar di Jawa Tengah. MAJALAH LONTAR, 33(1), 53-60. https://doi.org/10.26877/ltr.v33i1.7511.

Ramdhani, M. A. (2017). Lingkungan Pendidikan dalam Implementasi Pendidikan Karakter. Jurnal Pendidikan UNIGA, 8(1), 28-37. http://journal.uniga.ac.id/index.php/JP/article/view/69.

Rizqi, A. K., Suwandi, S., \& Suhita, R. (2018). Aspek Diksi serta Nilai-Nilai Pendidikan Karakter dalam Novel $\begin{array}{lllll}\text { Ayah Karya Hirata. } & \text { Bndrea }\end{array}$ https://jurnal.fkip.uns.ac.id/index.php/bhs_indonesia/article/view/12221.

Samrin, S. (2016). Pendidikan Karakter (Sebuah Pendekatan Nilai). Al-TA'DIB: Jurnal Kajian Ilmu Kependidikan, 9(1), 120-143. https://doi.org/10.31332/atdb.v9i1.505.

Santika, I. G. N. (2017). Kepala Sekolah Dalam Konsep Kepemimpinan Pendidikan: Suatu Kajian Teoritis. Widya Accarya, 7(1). http://ejournal.undwi.ac.id/index.php/widyaaccarya/article/view/898.

Santika, I. G. N. (2018). Strategi Meningkatkan Kualitas SDM Masyarakat Desa Padangsambian Kaja melalui Pendidikan Karakter Berbasiskan Kepedulian Lingkungan untuk Membebaskannya dari Bencana Banjir. Widya Accarya, http://103.207.99.162/index.php/widyaaccarya/article/view/941.

Santika, I. G. N. (2021). Grand Desain Kebijakan Strategis Pemerintah dalam Bidang Pendidikan untuk Menghadapi Revolusi Industri 4.0. Jurnal Education and Development, 9(2), 369-377. https: //doi.org/10.37081/ed.v9i2.2500.

Sugiyono. (2014). Metode Penelitian Pendidikan Pendekatan Kuantitatif, Kualitatif, dan R\&D. Alfabeta.

Surasmini, S., Joebagio, H., \& Wasino, W. (2014). Analisis Pelaksanaan Pendidikan Karakter di SMA Negeri 3 Semarang (Studi pada Kelompok Mata Pelajaran IPS). HISTORIKA, 20(1). 
https://jurnal.uns.ac.id/historika/article/view/29492.

Surawati, N. M., \& Suasthi, I. G. A. (2019). Integrasi Penguatan Pendidikan Karakter (PPK) dalam Penyusunan Perangkat Pembelajaran Pendidikan Agama Hindu di Sekolah Dasar. Widyanatya, 1(1), 21-35. https://doi.org/10.32795/widyanatya.v1i1.268.

Sutiyono, S. (2018). Reformulasi Pendidikan Pancasila dan Kewarganegaraan untuk Menguatkan Nasionalisme Warga Negara Muda di Wilayah Perbatasan. Citizenship Jurnal Pancasila dan Kewarganegaraan, 6(1), 1. https://doi.org/10.25273/citizenship.v6i1.1824.

Swarniti, N. W. (2021a). A Corpus Based Approach to the Analysis of Structures in Prepositional Phrase. Yavana Bhasha: Journal of English Language Education, 4(1), 18-22. https://doi.org/10.25078/yb.v4i1.2207.

Swarniti, N. W. (2021b). The Analysis of Semantics Meaning Found in Comments of Instagram Account of Info Denpasar. Prosiding Seminar Nasional Linguistik dan Sastra (SEMNALISA), 193-199. http://ejournal.unmas.ac.id/index.php/semnalisa/article/download/2369/1794.

Wahyudi, D. J., Purnomo, \& Yoto. (2019). Kompetensi Guru Keahlian Ganda Pasca Pelatihan On-In-On-In. Jurnal Pendidikan: Teori, Pelatihan dan Pengembangan, 4(6), 821-827. https://doi.org/10.17977/jptpp.v4i6.12547.

Widyana, I. K. (2018). Pendidikan Agama Hindu Berbasis Kearifan Lokal Kaharingan melalui Mata Kuliah Tawur di Sekolah Tinggi Agama Hindu Negeri Tampung Penyang Palangka Raya. Dharmasmrti: Jurnal Ilmu Agama dan Kebudayaan, 18(2), 101-113. https://doi.org/10.32795/ds.v9i2.152.

Wijanarti, W., Degeng, I. N. S., \& Untari, S. (2019). Problematika Pengintegrasian Penguatan Pendidikan Karakter pada Pembelajaran Tematik. Jurnal Pendidikan: Teori, Penelitian, dan Pengembangan, 4(3), 393-398. https://doi.org/10.17977/jptpp.v4i3.12161.

Yusanti, D., \& Kistian, A. (2020). Analisis Strategi Guru dalam Menanamkan Nilai Pendidikan Karakter di SD Negeri Gunung Keling. Bina Gogik: Jurnal Ilmiah Pendidikan Guru Sekolah Dasar, 7(2). https://www.ejournal.stkipbbm.ac.id/index.php/pgsd/article/view/529. 